\title{
Regulatory mechanism of NOV/CCN3 in the inflammation and apoptosis of lung epithelial alveolar cells upon lipopolysaccharide stimulation
}

\author{
HAI-PING ZHU ${ }^{1,2}$, HUI-YA HUANG ${ }^{2}$, DENG-MIN WU ${ }^{3}$, NIAN DONG $^{4}$, LI DONG $^{4}$, \\ CHENG-SHUI CHEN ${ }^{4}, \mathrm{CHAO}^{-L E I ~ \mathrm{CHEN}^{4}}$ and YU-GUO CHEN ${ }^{1}$
}

\author{
${ }^{1}$ Department of Emergency Medicine and Chest Pain Center, Clinical Research Center for Emergency and \\ Critical Care Medicine of Shandong, Key Laboratory of Emergency and Critical Care Medicine, \\ Key Laboratory of Cardiopulmonary-Cerebral Resuscitation Research, Qilu Hospital, Shandong University, \\ Jinan, Shandong 250012; ${ }^{2}$ Department of Intensive Care Unit, First Affiliated Hospital of Wenzhou Medical University; \\ ${ }^{3}$ Department of Rehabilitation Medicine, Second Affiliated Hospital of Wenzhou Medical University; \\ ${ }^{4}$ Department of Respiratory and Critical Care Medicine, First Affiliated Hospital of \\ Wenzhou Medical University, Wenzhou, Zhejiang 325000, P.R. China
}

Received April 6, 2019; Accepted August 20, 2019

DOI: $10.3892 / \mathrm{mmr} .2019 .10655$

\begin{abstract}
Lipopolysaccharide (LPS) induces inflammatory stress and apoptosis. Pulmonary epithelial cell apoptosis has been shown to accelerate the progression of acute lung injury (ALI)/acute respiratory distress syndrome (ARDS), and is the leading cause of mortality in patients with ALI/ARDS. Nephroblastoma overexpressed (NOV; also known as CCN3), an inflammatory modulator, is reported to be a biomarker in ALI. Using an LPS-induced ALI model, we investigated the expression of CCN3 and its possible molecular mechanism involved in lung alveolar epithelial cell inflammation and apoptosis. Our data revealed that LPS treatment greatly increased the level of CCN3 in human lung alveolar type II epithelial cells (A549 cell line). The A549 cells were also transfected with a specific CCN3 small interfering RNA (siRNA). CCN3 knockdown not only largely attenuated the expression of inflammatory cytokines, interleukin (IL)- $1 \beta$ and transforming growth factor (TGF)- $\beta 1$, but also reduced the apoptotic rate of the A549 cells and altered the expression of apoptosis-associated proteins (Bcl-2 and caspase-3).
\end{abstract}

Correspondence to: Professor Yu-Guo Chen, Department of Emergency Medicine and Chest Pain Center, Clinical Research Center for Emergency and Critical Care Medicine of Shandong, Key Laboratory of Emergency and Critical Care Medicine, Key Laboratory of Cardiopulmonary-Cerebral Resuscitation Research, Qilu Hospital, Shandong University, 107 Wenhua Xi Road, Jinan, Shandong 250012, P.R. China

E-mail: chen919085@sdu.edu.cn

Key words: CCN3, apoptosis, inflammation, acute lung injury, lung epithelial cells
Furthermore, CCN3 knockdown greatly inhibited the activation of nuclear factor (NF)- $\kappa \mathrm{B}$ p 65 in the A549 cells, and TGF- $\beta / p-$ Smad and NF- $\kappa$ B inhibitors significantly decreased the expression level of CCN3 in A549 cells. In conclusion, our data indicate that $\mathrm{CCN} 3$ knockdown affects the expression of downstream genes through the TGF- $\beta / \mathrm{p}-\mathrm{Smad}$ or $\mathrm{NF}-\kappa \mathrm{B}$ pathways, leading to the inhibition of cell inflammation and apoptosis in human alveolar epithelial cells.

\section{Introduction}

Acute lung injury (ALI) or its severe form, acute respiratory distress syndrome (ARDS), is characterized by an excessive and uncontrolled inflammatory response, which results in increased permeability of the alveolar-capillary barrier, alveolar flooding and acute respiratory failure $(1,2)$. Type II alveolar epithelial cells (AEC II), the progenitor cells in the corners of alveoli, are thought to play a central role in the pathogenesis of ALI by synthesizing, secreting and reutilizing surfactant (3). In addition, the apoptosis of AEC II directly accelerates the progression of ALI, which is the leading cause of mortality in patients with ARDS (4-6).

The nephroblastoma overexpressed protein (NOV/CCN3), is a cysteine-rich protein that belongs to the CCN (Cyr61, CTGF, Nov) family of matricellular proteins with a variety of functions $(7,8)$. CCN3 has been previously shown to be involved in regulating a variety of chronic inflammatory diseases, such as atherosclerosis, rheumatoid arthritis and liver disease $(7,9,10)$. In addition, studies have also shown that CCN proteins are key signaling and regulatory molecules involved in the pathophysiology of various lung diseases, including lung cancer, chronic obstructive pulmonary disease and ventilator-induced lung injury (11-15). By integrating the proteomic profiles of inflammatory mediators with clinical informatics, our previous study (16) indicated that the plasma levels of 
CCN3 and other inflammatory mediators were significantly increased in patients with severe pneumonia-induced ARDS compared to the healthy controls. Thus, we hypothesized that CCN3 could play a role in the pathophysiology of ALI/ARDS.

Proteins involved in transcriptional regulation, such as nuclear factor (NF)- $\kappa \mathrm{B}$ and transforming growth factor (TGF)- $\beta$, have been implicated in the development and progression of ALI and ARDS (17-21). Human A549 alveolar epithelial cells have been widely used as an epithelial cell injury model to examine lipopolysaccharide (LPS)-induced acute lung inflammatory response (22-28). The objective of this study was to reveal the potential role and underlying mechanism of CCN3 in lung dysfunction from the perspective of inflammation and apoptosis using siRNA-mediated transfection approach.

\section{Materials and methods}

Reagents and chemicals. Human lung alveolar type II epithelial A549 cells were obtained from the Cell Bank of the Chinese Academy of Science (Shanghai, China). LPS (Sigma-Aldrich; Merck KGaA), anti-TGF- $\beta 1$ antibody (cat. no. ab64715, Abcam), ALK5 inhibitor (TP0427736; cat. no. S8700, Selleck Chemicals), pyrrolidine dithiocarbamate (PDTC; cat. no. S363302, Selleck Chemicals) and immunohistochemistry reagents and kits (Beyotime, China) were used in this study. Other reagents and chemicals were obtained from Western Biotechnology (China).

Lung alveolar epithelial cell culture. Human A549 cells were cultured in F12K medium (Gibco; Thermo Fisher Scientific, Inc.), containing $10 \% \mathrm{FBS}, 100 \mathrm{U} / \mathrm{ml}$ penicillin, and $100 \mathrm{mg} / \mathrm{ml}$ streptomycin, in a $37^{\circ} \mathrm{C} / 5 \% \mathrm{CO}_{2}$ atmosphere. The medium was routinely changed every 3 days to remove non-adherent cells.

siRNA transfection. Cells were transfected with $100 \mathrm{nM}$ negative control (NC)-siRNA or CCN3-siRNA (Invitrogen; Thermo Fisher Scientific, Inc.) using Lipofectamine 2000 (cat. no. 11668019; Invitrogen; Thermo Fisher Scientific, Inc.) according to the manufacturer's instructions (29).

Enzyme-linked immunosorbent assay (ELISA). The levels of tumor necrosis factor (TNF)- $\alpha$, IL- $1 \beta$ and TGF- $\beta 1$ in the supernatant of cultured cells were analyzed using sandwich ELISA kits (cat. nos. F02810, F01220 and F02750; Bio-Tek Inc., USA), respectively, according to the manufacturer's instructions. The optical density of each well was assayed at $450 \mathrm{~nm}$ on a microplate reader.

Flow cytometric analysis. BD Pharmingen ${ }^{\mathrm{TM}}$ FITC Annexin V Apoptosis Detection Kit I (cat. no. 556547; BD Biosciences) was used to quantify apoptotic cells according to the manufacturer's instructions. After the treatments, cells were harvested, trypsinized, and rinsed twice with PBS. The suspended cells were incubated with $5 \mu$ l Annexin V-FITC solution and $5 \mu 1$ propidium iodide (PI) solution at $4^{\circ} \mathrm{C}$ for $15 \mathrm{~min}$. The cells were then suspended in $400 \mu \mathrm{l}$ binding buffer and subjected to flow cytometry (BD Biosciences), and the rates of apoptotic and necrotic cells were determined using CytExpert 2.3.0.84 (Beckman Coulter, Inc.).
Table I. Sequences of primers used for reverse transcription-quantitative PCR.

\begin{tabular}{ll}
\hline Genes & \multicolumn{1}{c}{ Primer sequences (5'-3') } \\
\hline$C C N 3$ & Forward GGAGGATTCACTGGGAGGC \\
$(153 \mathrm{bp})$ & Reverse ATTGACGGTTCCTATTGGTGAC \\
$B c l-2$ & Forward AGGGACGGGGTGAACTGG \\
$(175 \mathrm{bp})$ & Reverse CTACCCAGCCTCCGTTATCC \\
$T G F-\beta 1$ & Forward CGTGGAGGGGAAATTGAGG \\
$(185 \mathrm{bp})$ & Reverse GCCATGAGAAGCAGGAAAGG \\
GAPDH & Forward ATCCCATCACCATCTTCCAGG \\
$(146 \mathrm{bp})$ & Reverse GATGACCCTTTTGGCTCCC
\end{tabular}

$C C N 3$, nephroblastoma overexpressed (also known as NOVTGF- $\beta 1$, transforming growth factor- $\beta 1$.

Real-time quantitative PCR ( $q P C R)$. Total RNA was extracted from A549 cells using Trizol reagent (Beyotime, China), and then used for first-strand cDNA synthesis. qPCR was performed using an Applied Biosystems ${ }^{\mathrm{TM}}$ SYBR Green I Real-Time PCR Master Mix system (Funglyn Biotech, Canada). The amplification program was set to $94^{\circ} \mathrm{C}$ for $4 \mathrm{~min}$, 35 cycles of $94^{\circ} \mathrm{C}$ for $20 \mathrm{sec}$ and $60^{\circ} \mathrm{C}$ for $30 \mathrm{sec}$, and $72^{\circ} \mathrm{C}$ for $30 \mathrm{sec}$ as a final elongation step. The gene expression level was normalized to GAPDH as the internal gene using the $2^{-\Delta \Delta \mathrm{Cq}}$ method (30). The primer sequences used in this study are shown in Table I.

Western blot analysis. A549 cells were seeded at a density of $1 \times 10^{6}$ cells with $0.1 \mathrm{ml}$ RIPA buffer. After passaging and centrifugation $(12,000 \mathrm{x} \mathrm{g}$ for $15 \mathrm{~min})$, the supernatants were collected and protein concentrations were assessed using the Bradford assay. An equal amount of protein $(20 \mu \mathrm{g})$ was loaded onto $10 \%$ SDS-PAGE gels. Proteins were resolved through SDS-PAGE and transferred to polyvinylidene difluoride (PVDF) membranes (Bio-Rad). Nonspecific sites were blocked with $5 \%$ nonfat milk at room temperature for $2 \mathrm{~h}$. The blots were incubated with antibodies against Bcl-2 (dilution 1:500, cat. no. ab182858; Abcam), caspase-3 (dilution 1:500, cat. no. ab184787), TGF- $\beta$ receptor (R)II (dilution 1:500, cat. no. ab113670, Abcam), p-Smad2/3 [dilution 1:500, cat. no. 8828S, Cell Signaling Technology, Inc. (CST)], CCN3 (dilution 1:500; cat. no. ab191425; Abcam) and $\beta$-actin (dilution 1:1,000; cat. no. ab8226; Abcam) at room temperature for $1.5 \mathrm{~h}$ or $4^{\circ} \mathrm{C}$ overnight. After washing with TBST three times, the blots were incubated with the secondary goat anti-rat IgG antibody (dilution 1:1,000; cat. no. AP156P; Sigma-Aldrich; Merck KGaA) at room temperature for $1.5 \mathrm{~h}$, and visualized using an enhanced chemiluminescence (ECL) kit (cat. no. 34580; Thermo Fisher Scientific, Inc.) in the ImageQuant Tanon-4200 system (Tanon Science and Technology Co., Ltd., Shanghai, China). The rat anti- $\beta$-actin $\mathrm{Ab}$ was used as an internal control for western blotting. The densities of the detected bands were quantified in triplicate using Labworks $^{\mathrm{TM}}$ Analysis Software (UVP, LLC, USA). 
A
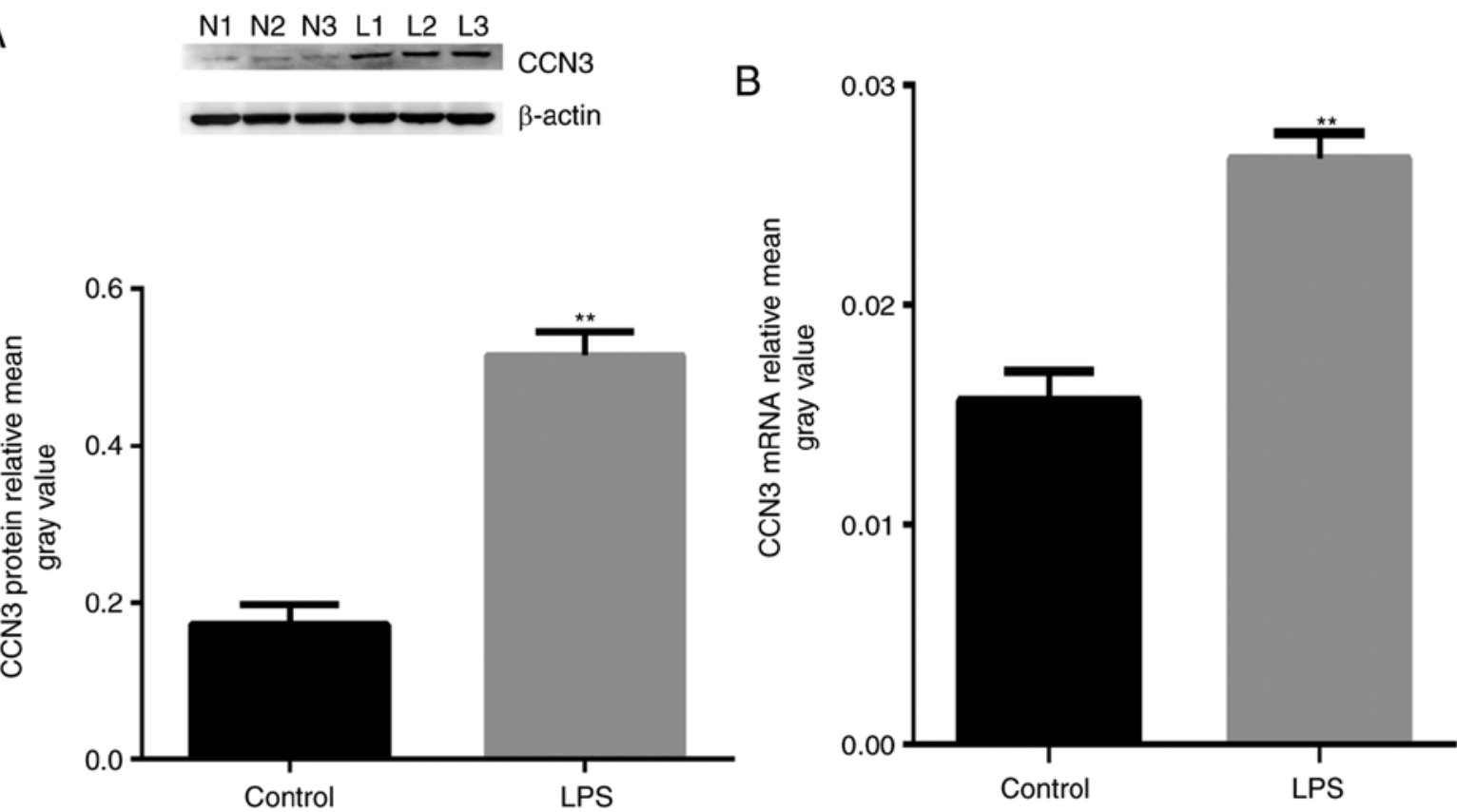

Figure 1. Effects of LPS treatment on CCN3 expression in A549 cells. (A) CCN3 protein expression in A549 cells in response to $0.1 \mu \mathrm{g} / \mathrm{ml}$ LPS treatment for $12 \mathrm{~h}$, as assessed by western blot analysis (N1-N3, normal; L1-L3, LPS-treated). (B) CCN3 mRNA levels in A549 cells in response to $0.1 \mu \mathrm{g} / \mathrm{ml}$ LPS treatment for $12 \mathrm{~h}$, as assessed with qPCR. ${ }^{* *} \mathrm{P}<0.01$ vs. the control group. LPS, lipopolysaccharide; CCN3, nephroblastoma overexpressed (also known as NOV).
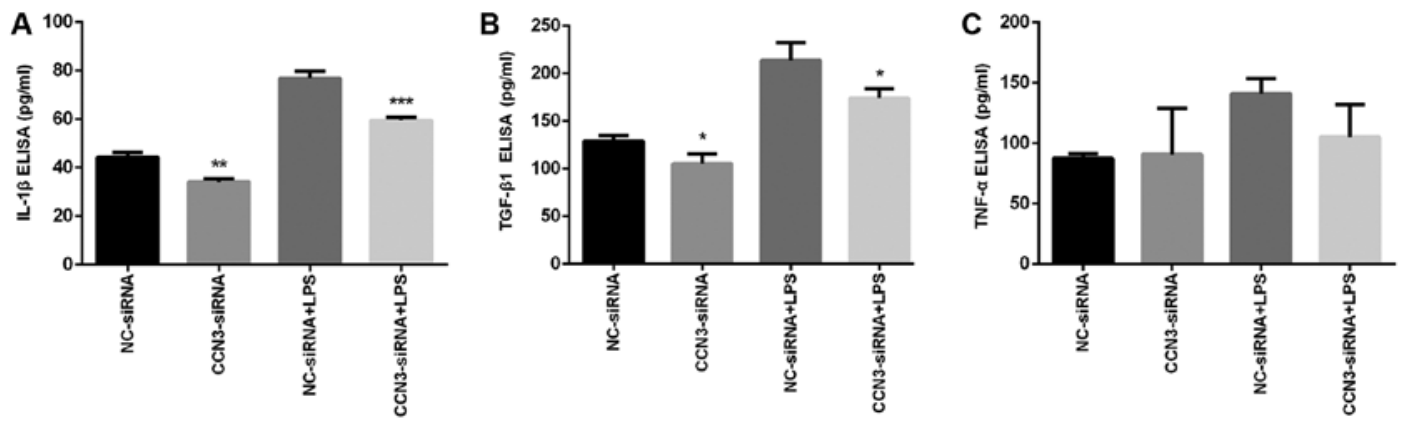

Figure 2. Effects of CCN3 siRNA treatment on the expression of inflammatory cytokines. A549 cells were treated with NC-siRNA or CCN3-siRNA for $36 \mathrm{~h}$, and then incubated with or without $0.1 \mu \mathrm{g} / \mathrm{ml}$ LPS for an additional $12 \mathrm{~h}$. The expression levels of (A) IL-1 $\beta$, (B) TGF- $\beta 1$ and (C) TNF- $\alpha$ were assessed in vitro with ELISA. Data are presented as means \pm SEM. ${ }^{*} \mathrm{P}<0.05,{ }^{* *} \mathrm{P}<0.01,{ }^{* * *} \mathrm{P}<0.001$ vs. respective siRNA-NC. NC-siRNA, siRNA-negative control group; CCN3-siRNA, CCN3 siRNA-transfected group; LPS, lipopolysaccharide; CCN3, nephroblastoma overexpressed (also known as NOV); IL, interleukin; TGF, transforming growth factor; TNF, tumor necrosis factor.

Immunofluorescence staining. Cells were grown on 12-mm glass coverslips. After transfection with CCN3-siRNA or NC-siRNA, the cells were fixed in $4 \%$ paraformaldehyde at room temperature for $15 \mathrm{~min}$, permeabilized in PBS with $0.5 \%$ Triton X-100 for 15 min, and blocked with 6\% goat serum for $30 \mathrm{~min}$. Next, the cells were incubated with the primary NF- $\mathrm{BB}$ p65 antibody (dilution 1:100, cat. no. ab32536, Abcam) solution at $4^{\circ} \mathrm{C}$ overnight. After washing, the cells were incubated with the secondary antibody, goat anti-rabbit IgG (Cy3; dilution 1:800, cat. no. ab6939, Abcam) at room temperature for $30 \mathrm{~min}$, and DAPI was added for nuclear staining for $5 \mathrm{~min}$. Finally, the cells were visualized using a confocal laser scanning microscope (Leica, Germany). The data are presented as relative fluorescence intensity.

Statistical analysis. Statistical analysis was performed with Statistical Product and Service Solutions (SPSS) v24.0 (SPSS,
Inc.) and Prism 6 (GraphPad Software). Data are presented as means \pm SEM. Statistical significance was assessed with Student's t-test or one-way ANOVA with Bonferroni significant analysis. Results were considered statistically significant when $\mathrm{P}<0.05$.

\section{Results}

Effect of LPS on the expression level of CCN3 in human lung alveolar epithelial cells. To assess the effects of LPS on CCN3 expression, we analyzed mRNA expression by qPCR and protein expression by western blot analysis. The results revealed that the levels of $\mathrm{CCN} 3 \mathrm{mRNA}$ and $\mathrm{CCN} 3$ protein were significantly upregulated following treatment with $0.1 \mu \mathrm{g} / \mathrm{ml}$ LPS for $12 \mathrm{~h}$ (Fig. $1 \mathrm{~A}$ and $\mathrm{B})(\mathrm{P}<0.01)$. Our findings suggest that $\mathrm{CCN} 3$ is associated with LPS-induced lung injury. 
A

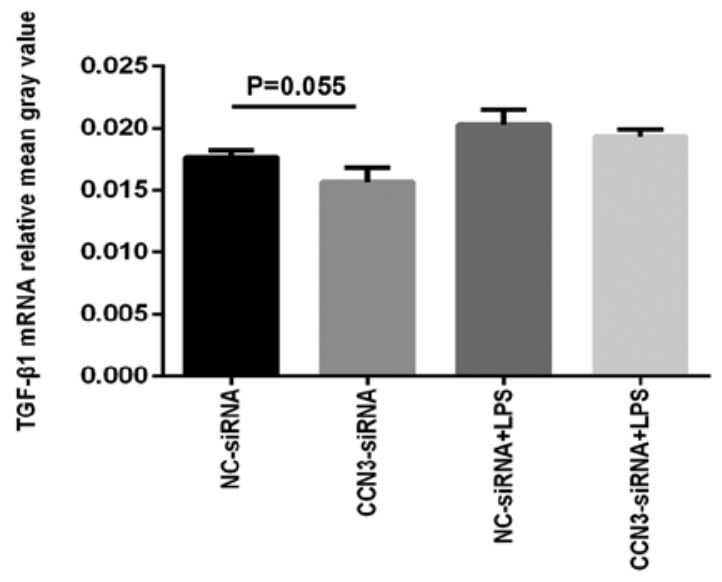

C

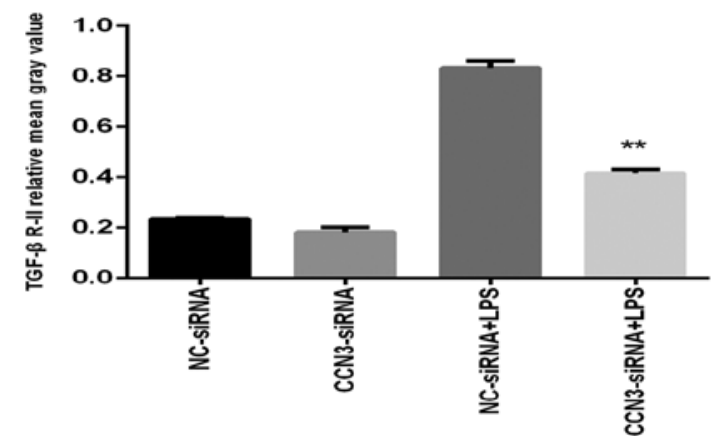

$E$

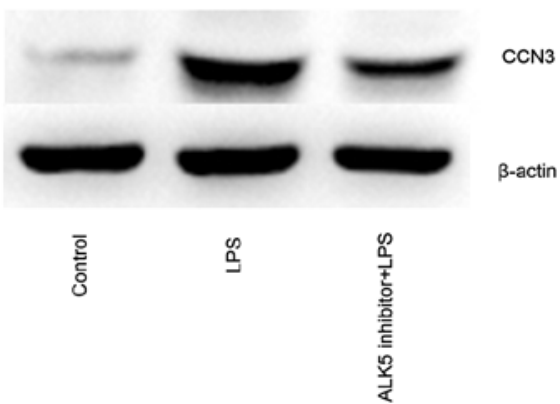

B

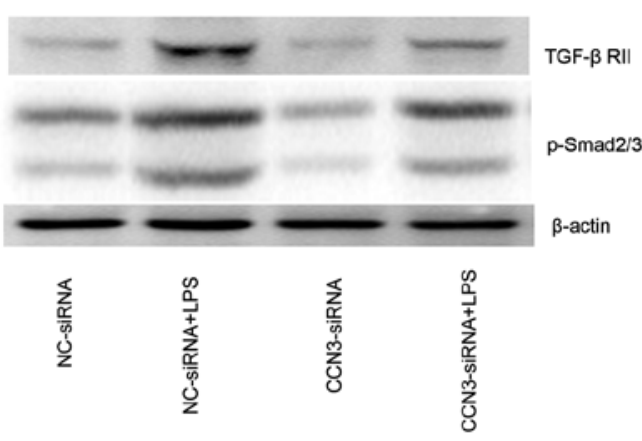

D

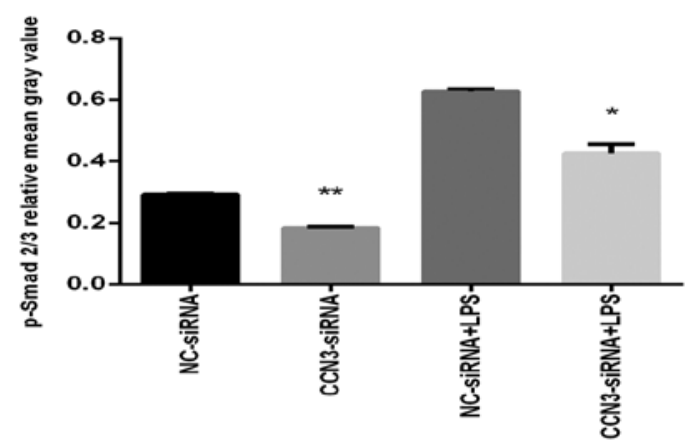

$\mathrm{F}$

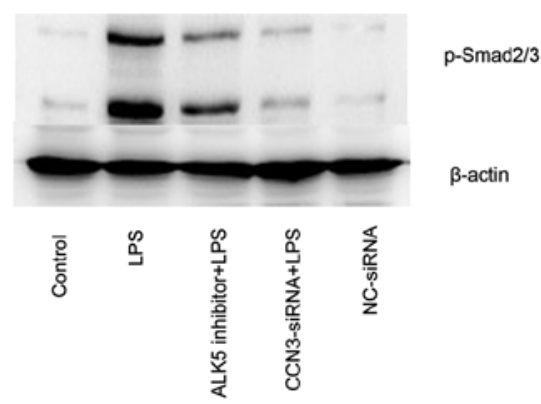

Figure 3. The anti-inflammatory activity of CCN3 gene silencing involves TGF- $\beta / \mathrm{p}-\mathrm{Smad}$ signaling. (A) TGF- $\beta 1 \mathrm{mRNA}$ levels were determined by qPCR. (B-D) TGF- $\beta$ RII and p-Smad2/3 protein levels were assessed by western blot analysis. ${ }^{*} \mathrm{P}<0.05,{ }^{* *} \mathrm{P}<0.01$ vs. respective NC-siRNA. (E and F) After $36 \mathrm{~h}$ of CCN3-siRNA transfection or not, A549 cells were pretreated with ALK5 inhibitor $(10 \mu \mathrm{M})$ for $30 \mathrm{~min}$, followed by stimulation with LPS $(0.1 \mu \mathrm{g} / \mathrm{ml})$ or $0.1 \%$ DMSO for $12 \mathrm{~h}$. The protein levels of (E) CCN3 and (F) p-Smad2/3 were assessed with western blot analysis. NC-siRNA, siRNA-negative control group; CCN3-siRNA, CCN3 siRNA-transfected group; LPS, lipopolysaccharide; $\mathrm{CCN} 3$, nephroblastoma overexpressed (also known as NOV); TGF, transforming growth factor.

Reduction of inflammatory cytokines by CCN3-siRNA. To assess the function of $\mathrm{CCN} 3$ in the regulation of inflammatory cytokines, we inhibited CCN3 expression by siRNA and measured the levels of TNF- $\alpha$, IL- $1 \beta$ and TGF- $\beta 1$ by ELISA. As shown in Fig. 2A and B, it was demonstrated that inhibition of CCN3 by siRNA significantly downregulated the levels of inflammatory cytokines, such as IL-1 $\beta(\mathrm{P}<0.01)$ and TGF- $\beta 1$ $(\mathrm{P}<0.05)$, compared with the vehicle control $(\mathrm{NC})$. Similar effects were observed after LPS treatment. Surprisingly, there were no significant changes in the levels of TNF- $\alpha$ after CCN- siRNA treatment compared with both the NC group and following LPS treatment (Fig. 2C).

Anti-inflammatory activity of CCN3-siRNA through modulation of TGF- $\beta / p$-Smad signaling. Activation of TGF- $\beta$ though interaction with receptor-regulated Smad (Smad2/3) signaling plays a pro-inflammatory role in the resolution of lung alveolar epithelial cell injury $(18,31)$. We next sought to explore whether the CCN3-induced pro-inflammatory effects are mediated through the TGF- $\beta / \mathrm{p}$-Smad signaling pathway. To investigate this, A549 cells were transfected with CCN3-siRNA for $36 \mathrm{~h}$ and then stimulated with or without LPS for $12 \mathrm{~h}$. The mRNA level of TGF- $\beta 1$, and the protein levels of TGF- $\beta$ RII and p-Smad $2 / 3$ were detected by qPCR and western blot analysis, respectively. We found that knockdown of CCN3 by siRNA largely downregulated the protein levels of TGF- $\beta$ RII and p-Smad $2 / 3$ (Fig. 3B-D). However, the mRNA level of TGF- $\beta 1$ was slightly decreased, without statistical significance $(\mathrm{P}=0.055)$ (Fig. 3A). In addition, we confirmed that pretreatment of the cells with TP0427736 (an ALK5 inhibitor), which inhibits the TGF- $\beta$ / p-Smad signaling pathway, greatly prevented the overexpression of CCN3 induced by LPS treatment, while knockdown of CCN3 by siRNA effectively attenuated the LPS-induced $\mathrm{p}-\mathrm{Smad} 2 / 3$ expression (Fig. 3E and F). To conclude, the anti-inflammatory activity of CCN3-siRNA in LPS-induced lung injury is modulated by TGF- $\beta / \mathrm{p}-$ Smad signaling. 

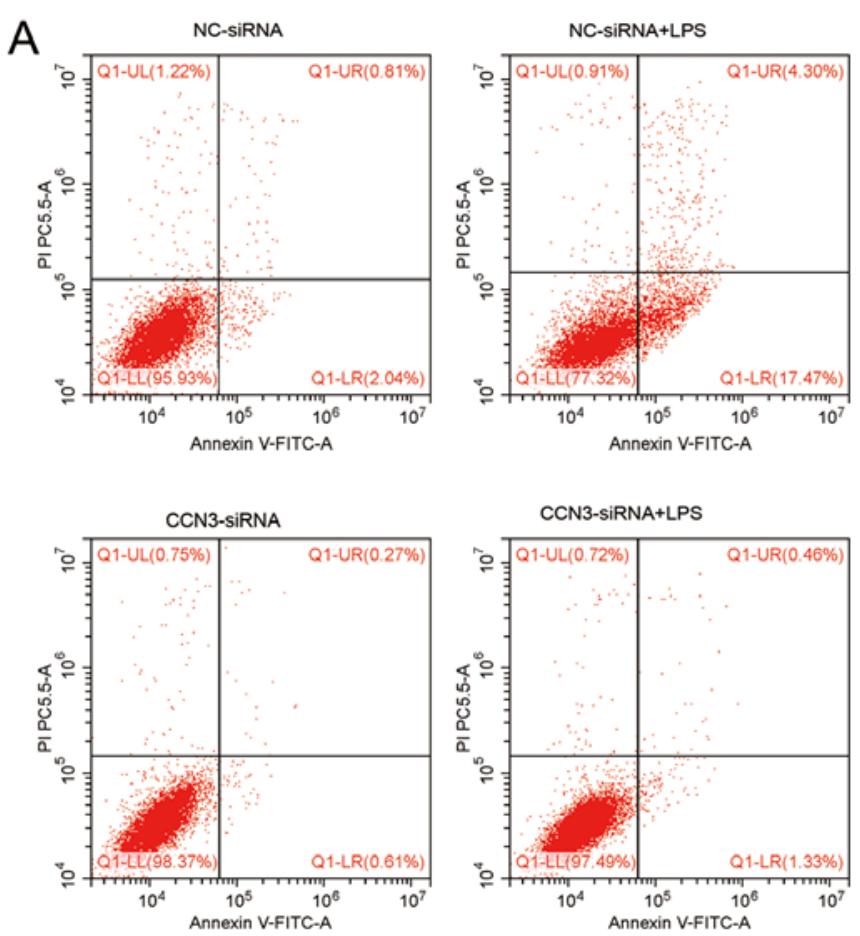

B
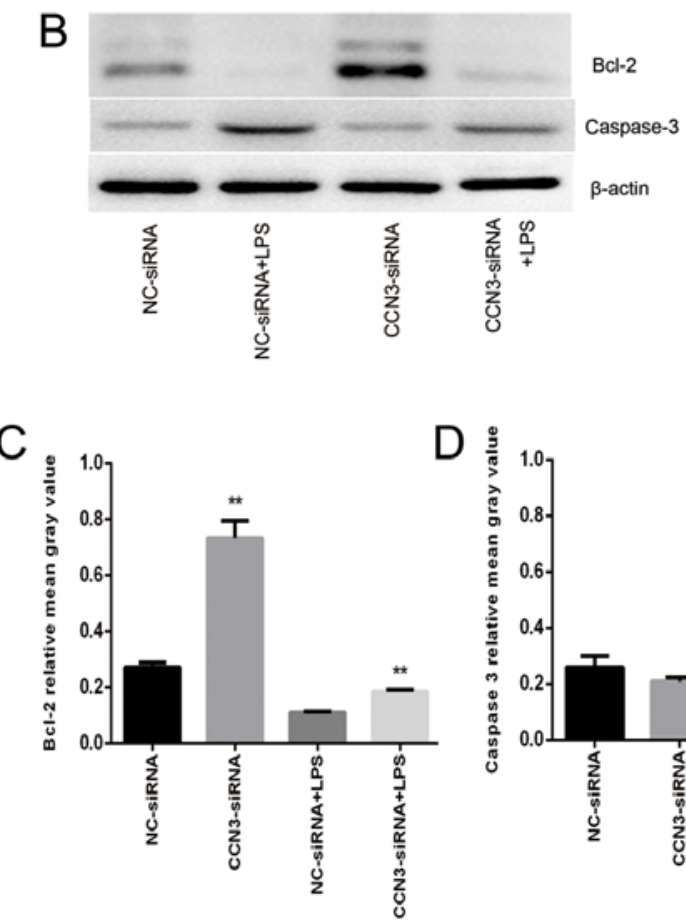

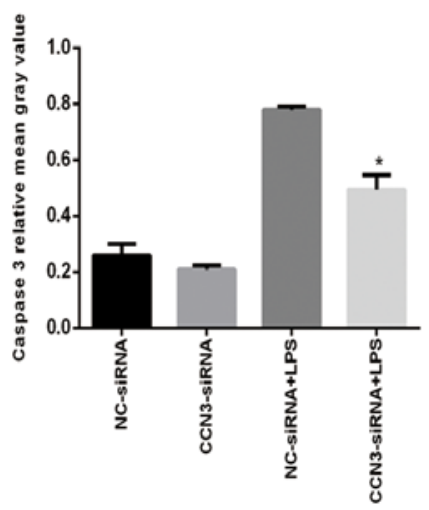

Figure 4. CCN3-siRNA mediates anti-apoptotic effects through Bcl-2/caspase-3 activation. (A) Flow cytometry was used to detect the proportion of cell apoptosis in three repeated experiments. (B-D) CCN3-siRNA-mediated anti-apoptotic effects in A549 cells through Bcl-2/caspase-3 activation. Western blot analysis was repeated at least three times. ${ }^{*} \mathrm{P}<0.05,{ }^{, *} \mathrm{P}<0.01$ vs. respective NC-siRNA. NC-siRNA, siRNA-negative control group; CCN3-siRNA, CCN3 siRNA-transfected group; $\mathrm{CCN} 3$, nephroblastoma overexpressed (also known as NOV).

Suppression of CCN3 inhibits apoptosis in A549 cells through the Bcl-2/caspase-3 pathway. Lung epithelial cell apoptosis is increased after LPS treatment (24). Bcl-2 is an important anti-apoptotic factor, and decreased expression of Bcl-2 can lead to the activation of caspase- 3 and apoptosis (32). To assess the effect of $\mathrm{CCN} 3$ on apoptosis, we performed flow cytometry using an apoptosis detection kit. Our observations indicated that the sum of the proportions of early apoptosis and late apoptosis was significantly decreased in the CCN3 knockdown group with or without LPS treatment, but increased after LPS treatment compared with the negative group $(\mathrm{P}<0.001$; Fig. $4 \mathrm{~A})$. In addition, the western blot assays revealed that silencing of $\mathrm{CCN} 3$ expression upregulated $\mathrm{Bcl}-2$ protein levels and downregulated the expression of caspase- 3 protein, also after LPS treatment (Fig. 4B-D). Our data suggest that CCN3 is associated with the apoptosis of lung epithelial cells.

CCN3-siRNA knockdown reduces the activation of the NF- $\kappa B$ signaling pathway. A previous study demonstrated that LPS could cause the activation of NF- $\mathrm{KB}$, which is involved in the process of apoptosis in ALI/ARDS (33). In order to establish whether the CCN3-induced pro-apoptotic effects are mediated through the NF- $\mathrm{kB}$ signaling pathway, we used confocal microscopy to analyze the localization of NF- $\kappa$ B p 65 and western blot analysis of cytoplasmic and nuclear NF- $\kappa B$ p65 expression levels to establish whether nuclear translocation activation occurs. The results demonstrated that activation of NF- $\mathrm{KB}$ was largely reduced in the $\mathrm{CCN} 3$ knockdown group, whereas it was greatly stimulated after LPS exposure (Fig. 5A). As shown in Fig. 5B, pretreatment of the cells with
PDTC, which inhibits the NF-kB signaling pathway, significantly attenuated the overexpression of $\mathrm{CCN} 3$ induced by LPS treatment. Meanwhile, the protein expression levels of NF- $\kappa \mathrm{B}$ p65 in the nucleus following pretreatment with PDTC or CCN3 knockdown, were significantly decreased compared to those without pretreatment, namely the LPS-treated only group $(\mathrm{P}<0.001$, Fig. $5 \mathrm{C})$. Therefore, we suggest that $\mathrm{CCN} 3$ caused activation of NF- $\mathrm{KB}$ in A549 cells by the promotion of nuclear translocation of NF- $\kappa \mathrm{B}$ p65.

\section{Discussion}

Acute lung injury (ALI)/acute respiratory distress syndrome (ARDS) is a highly refractory disease, and its complex pathology in lung epithelial cells is not fully understood. In the present study, we aimed to identify a potential signaling pathway to target in order to prevent or treat the disease. This study demonstrated that nephroblastoma overexpressed (NOV; also known as CCN3) is critical for LPS-induced lung alveolar epithelial cell injury and apoptosis. Firstly, we investigated the presence of $\mathrm{CCN} 3$ using an in vitro cell culture ALI model. We found that CCN3 mRNA and protein expression were significantly increased after LPS treatment. These observations confirmed that LPS treatment strongly induced the expression of $\mathrm{CCN} 3$ in lung alveolar epithelial cells. This was consistent with a previous study (16), revealing elevated $\mathrm{CCN} 3 / \mathrm{NOV}$ levels as a potential indicator for lung injury severity.

However, the precise biological role, mechanism of action and physiological function of $\mathrm{CCN} 3$ proteins in ARDS has remained elusive until recently. Kular et al (7) indicated that $\mathrm{CCN} 3$ expression in vitro is finely regulated by diverse 

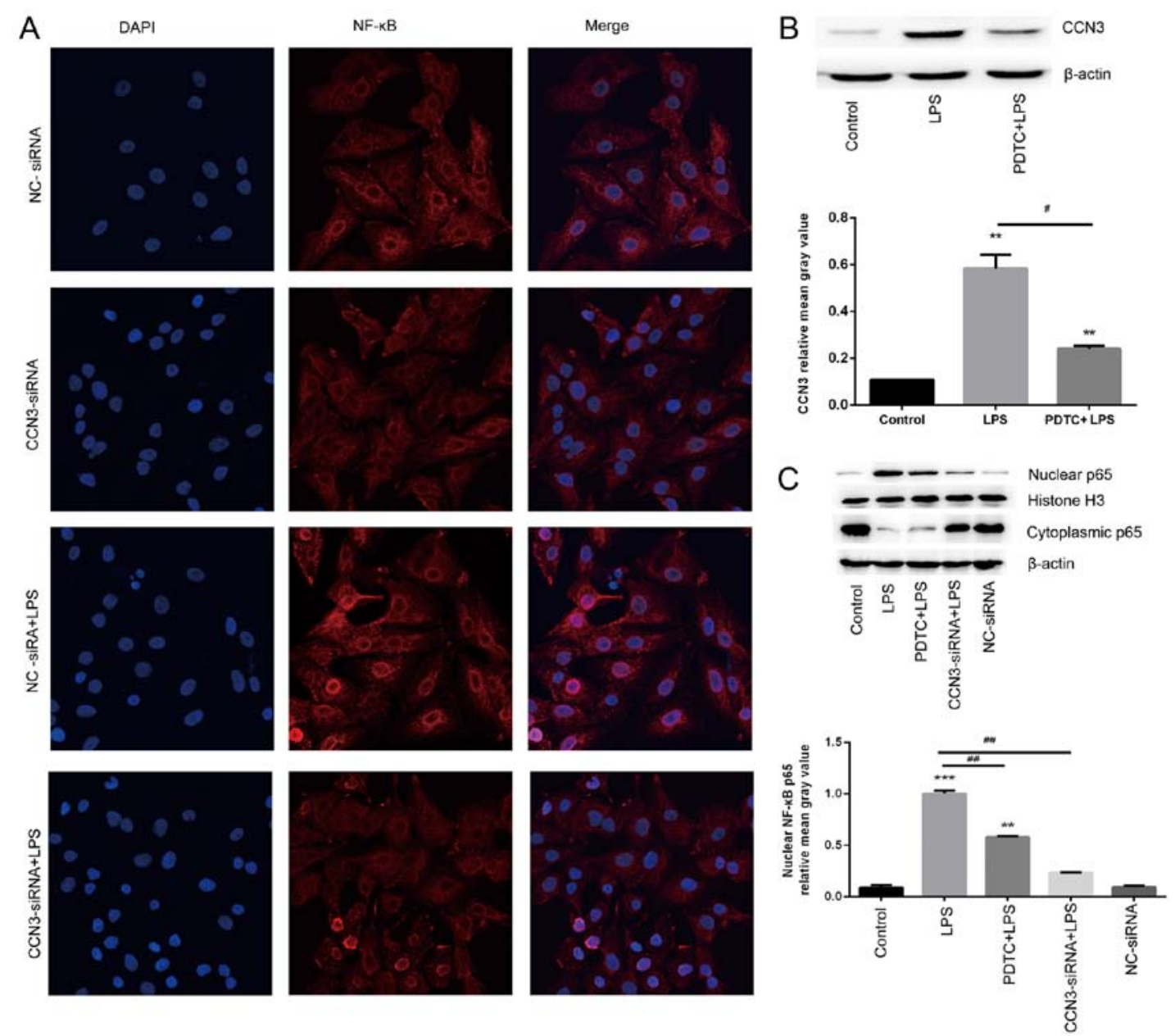

Figure 5. CCN3-siRNA knockdown inhibits the LPS-induced NF- $\mathrm{kB}$ signaling pathway. (A) Confocal microscopy of NF- $\mathrm{B}$ nuclear translocation in cultured A549 cells. Magnification x600. DAPI (blue), NF- $\mathrm{kB}$ p65 (red), in A549 cells challenged with LPS. (B and C) After $36 \mathrm{~h}$ of CCN3-siRNA transfection or not, cells were pretreated with PDTC $(10 \mu \mathrm{M})$ for $30 \mathrm{~min}$, followed by stimulation with LPS $(0.1 \mu \mathrm{g} / \mathrm{ml})$ for $12 \mathrm{~h}$. The protein levels of (B) CCN3 and (C) NF- $\mathrm{kB}$ p65 in the cytoplasm and nucleus were assessed by western blot analysis. ${ }^{* *} \mathrm{P}<0.01,{ }^{* * * *} \mathrm{P}<0.001$ vs. control group; ${ }^{*} \mathrm{P}<0.05,{ }^{\# \#} \mathrm{P}<0.01$ vs. LPS group. NC-siRNA, siRNA-negative control group; CCN3-siRNA, CCN3 siRNA-transfected group; CCN3, nephroblastoma overexpressed (also known as NOV); LPS, lipopoly-

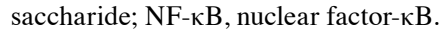

inflammatory mediators and cytokines, such as TNF- $\alpha$, IL-1 $\beta$ and TGF- $\beta$. In this study, an in vitro siRNA approach showed that inhibition of $\mathrm{CCN} 3$ significantly attenuated the expression levels of pro-inflammatory cytokines (IL-1 $\beta$ and TGF- $\beta 1$ ), which have been linked to the initiation and amplification of the inflammatory response in ALI/ARDS $(2,34)$. Surprisingly, we found no significant changes in the expression level of TNF- $\alpha$ after transfection with CCN3-siRNA. This could be explained by the insensitivity of TNF- $\alpha$ production by the alveolar epithelial cells in our study. TNF- $\alpha$ was possibly not involved in this process. In addition, recent studies have revealed that $\mathrm{CCNs}$ and TNF- $\alpha$ are co-expressed at sites of inflammation (35). It is therefore tempting to speculate that CCNs may help to counterbalance the inflammatory effects of TNF- $\alpha$. A previous study has shown that A549 cells release IL-1 $\beta$ and TNF- $\alpha$ after LPS stimulation though autocrine modes (36). This exerts a strong and synergic induction signal for IL-6 (37), since a high increase of IL-6 in ALI/ARDS accelerates the development of the local inflammatory microenvironment (38). Moreover, high levels of IL- $1 \beta$, IL- 6 and TNF- $\alpha$ have been considered as the most promising biomarkers for predicting morbidity and mortality in patients with ALI/ARDS (39). Taken together, we demonstrated that $\mathrm{CCN} 3$ plays an important pro-inflammatory role in lung epithelial cell injury by promoting the activities of specific cytokines, such as IL- $1 \beta$ and TGF- $\beta 1$.

TGF- $\beta 1$ is a secretory cytokine that binds to the Type II and Type I TGF $\beta$ receptor (TGF- $\beta$ RII and TGF- $\beta$ RI, respectively), which initiates TGF- $\beta$ signaling via Smad phosphorylation and nuclear translocation $(40,41)$. Many studies have demonstrated that the TGF- $\beta 1$ pathway plays a critical role in the development of ALI (18,40-42). One study has demonstrated that early activation of TGF- $\beta 1 /$ Smad2 signaling might contribute to acute pancreatitis-associated ALI, through regulation of lung permeability, epithelial ion transport, fibrinolysis and the extracellular matrix (31). In the present study, we observed a reduction in the levels of TGF- $\beta R$ II and p-Smad2/3 following CCN3 silencing. Notably, overexpression of CCN3 in A549 cells might contribute to the activation of the TGF- $\beta$ signaling pathway, leading to the destruction of epithelial integrity and aggregation of lung injury. Therefore, to further explore the direct roles of the TGF- $\beta$ and p-Smad2/3 signaling pathways in the effect of CCN3, TP0427736, which inhibits the phosphorylation of Smad2/3 (43), was chosen to treat the A549 cells. We observed a significant decrease in CCN3 expression induced by LPS after TP0427736 treatment in 
the A549 cells, suggesting that $\mathrm{CCN} 3$ may promote the release of inflammatory mediators by the TGF- $\beta / \mathrm{p}-\mathrm{Smad} 2 / 3$ signaling pathway in A549 cells. This reveals an alternative pathway that could aid in future studies of the pathogenesis of ALI.

Apoptosis of AEC II cells plays an essential role in the pathogenesis of ARDS (44). Our study showed that $0.1 \mu \mathrm{g} / \mathrm{ml}$ LPS could promote apoptosis in A549 cells. CCN3 knockdown greatly reduced the apoptotic rate of AEC II cells, while overexpression of CCN3 promoted AEC II apoptosis. LPS-triggered alveolar epithelial type II cell apoptosis is thought to primarily depend on the mitochondrial apoptosis signaling pathway (45). Bcl-2 regulates the mitochondrial apoptotic pathway by preventing the release of cytochrome $c$ from mitochondria to cytosol, and activating caspase-3 (46). Doghman et al (47) showed that CCN3 induced human adrenocortical cell apoptosis through the activation of caspase 3 . Consistent with these results, the changes in Bcl-2 and caspase- 3 levels highlighted that the inhibition of $\mathrm{CCN} 3$ expression prevented AEC II apoptosis at the cellular level. Therefore, the activation of CCN3 induced by LPS may be involved in promoting AEC II cell apoptosis through the Bcl-2/caspase-3 pathway.

Moreover, this study showed that $\mathrm{CCN} 3$ activated $\mathrm{NF}-\kappa \mathrm{B}$ in A549 cells by promoting nuclear translocation of NF- $\kappa \mathrm{B}$ p65. As a central mediator of the human immune response, $\mathrm{NF}-\kappa \mathrm{B}$ is a critical transcription factor in the pathogenesis of ALI (48). It directly activates downstream signaling pathways by interacting with MyD88, promoting the degradation of IкB $\alpha$ and the phosphorylation of NF- $\mathrm{BB}$ (49), leading to epithelial cell apoptosis by the Fas/Fas ligand (Fas L) signaling pathway (50-52). In addition, previous studies have demonstrated that the $\mathrm{NF}-\kappa \mathrm{B}$ pathway promoted lung inflammation and injury in response to local and systemic stresses in airway epithelial cells, by triggering the transcription of inflammatory cytokines and chemokines (TNF- $\alpha$, IL-1 $\beta$ and IL-6) (53-55). Because this study did not illuminate the relationship between IL- $1 \beta$ and $N F-\kappa B$, it is not clear whether the same response to stimuli could be observed in A549 cells. Additionally, overexpression of CCN3 has been observed to have anti-inflammatory effects on endothelial cells by inhibiting the activation of NF- $\mathrm{BB}(9)$, which is in contrast with our results. These differences may be due to differences in the cell types analyzed. Our results demonstrated that pretreatment with PDTC (a specific NF- $\kappa$ B inhibitor) significantly suppressed LPS-induced CCN3 and nuclear NF- $\mathrm{B}$ p 65 expression, indicating that $\mathrm{CCN} 3$ plays a role in human lung alveolar epithelial cells through the NF- $\mathrm{BB}$ signaling pathway. It has been shown that excessive epithelial cell apoptosis could lead to the damage of the pulmonary alveolar-capillary barrier and aggravate the inflammatory responses in lung diseases $(52,56)$, suggesting a close association between inflammation and apoptosis. In summary, our study revealed that $\mathrm{CCN} 3$ may have potential clinical value in the occurrence and development of ALI via the TGF- $\beta /$ p-Smad or NF- $\kappa$ B signaling pathways. Further research is needed to validate our findings using in vivo models, yet our data suggest a novel potential target for future clinical studies.

In conclusion, the present study demonstrated that $\mathrm{CCN} 3$ expression in alveolar epithelial cells was significantly increased under inflammatory conditions and/or in response to stimuli such as LPS. The overexpression of CCN3 can be perturbed by a TGF- $\beta / \mathrm{p}-\mathrm{Smad}$ or $\mathrm{NF}-\kappa \mathrm{B}$ inhibitor, which explains how $\mathrm{CCN} 3$-siRNA led to the inhibition of the release of inflammatory cytokines and apoptosis in human alveolar epithelial cells.

\section{Acknowledgements}

Not applicable.

\section{Funding}

This research study was supported by the Wenzhou Municipal Science and Technology Plan Project (grant no. 2017Y0877), National Key R\&D Program of China (grant nos. 2017YFC0908700 and 2017YFC0908703), Key R\&D Program of Shandong Province (grant no. 2016ZDJS07A14), Natural Science Foundation of Zhejiang Province (grant no. LY18H010006) and National Nature Science Foundation of China (grant no. 81600062).

\section{Availability of data and materials}

The datasets used and/or analyzed during the current study are available from the corresponding author on reasonable request.

\section{Authors' contributions}

HPZ, CSC and YGC conceived and designed the experiments, analyzed the data and wrote the manuscript. HYH, DMW, CLC, LD and ND carried out the experiments, prepared and analyzed the figures and tables. LD, CSC, CLC and YGC obtained the study materials and reagents in preparation for the experiments. All authors reviewed drafts of the paper. All authors read and approved the manuscript and agree to be accountable for all aspects of the research in ensuring that the accuracy or integrity of any part of the work are appropriately investigated and resolved.

\section{Ethics approval and consent to participate}

The protocol of the present study was approved by the Use Committee of Wenzhou Medical University (Wenzhou, China).

\section{Patient consent for publication}

Not applicable.

\section{Competing interests}

The authors declare that they have no competing interests.

\section{References}

1. Matthay MA, Ware LB and Zimmerman GA: The acute respiratory distress syndrome. J Clin Invest 122: 2731-2740, 2012.

2. Ware LB and Matthay MA: The acute respiratory distress syndrome. N Engl J Med 342: 1334-1349, 2000.

3. Rooney SA: Regulation of surfactant secretion. Comp Biochem Physiol A Mol Integr Physiol 129: 233-243, 2001

4. Galani V, Tatsaki E, Bai M, Kitsoulis P, Lekka M, Nakos G and Kanavaros P: The role of apoptosis in the pathophysiology of Acute Respiratory Distress Syndrome (ARDS): An up-to-date cell-specific review. Pathol Res Pract 206: 145-150, 2010. 
5. Imazu Y, Yanagi S, Miyoshi K, Tsubouchi H, Yamashita SI, Matsumoto N, Ashitani JI, Kangawa K and Nakazato M: Ghrelin ameliorates bleomycin-induced acute lung injury by protecting alveolar epithelial cells and suppressing lung inflammation. Eur J Pharmacol 672: 153-158, 2011.

6. Kutsukake M, Matsutani T, Tamura K, Matsuda A, Kobayashi M, Tachikawa E and Uchida E: Pioglitazone attenuates lung injury by modulating adipose inflammation. J Surg Res 189: 295-303, 2014.

7. Kular L, Pakradouni J, Kitabgi P, Laurent M and Martinerie C: The CCN family: A new class of inflammation modulators Biochimie 93: 377-388, 2011.

8. Perbal B: NOV (nephroblastoma overexpressed) and the CCN family of genes: Structural and functional issues. Mol Pathol 54 57-79, 2001.

9. Lin Z, Natesan V, Shi H, Hamik A, Kawanami D, Hao C, Mahabaleshwar GH, Wang W, Jin ZG, Atkins GB, et al: A nove role of CCN3 in regulating endothelial inflammation. J Cell Commun Signal 4: 141-153, 2010.

10. Wu W, Hu X, Zhou X, Klenotic PA, Zhou Q and Lin Z: Myeloid deficiency of $C \mathrm{CN} 3$ exacerbates liver injury in a mouse mode of nonalcoholic fatty liver disease. J Cell Commun Signal 12 389-399, 2018

11. Chen PP, Li WJ, Wang Y, Zhao S, Li DY, Feng LY, Shi XL Koeffler HP, Tong XJ and Xie D: Expression of Cyr61, CTGF and WISP-1 correlates with clinical features of lung cancer. PLoS One 2: e534, 2007.

12. Dolinay T, Kaminski N, Felgendreher M, Kim HP, Reynolds P, Watkins SC, Karp D, Uhlig S and Choi AM: Gene expression profiling of target genes in ventilator-induced lung injury. Physiol Genomics 26: 68-75, 2006.

13. Llinàs L, Peinado VI, Ramon Goñi J, Rabinovich R, Pizarro S, Rodriguez-Roisin R, Barberà JA and Bastos R: Similar gene expression profiles in smokers and patients with moderate COPD. Pulm Pharmacol Ther 24: 32-41, 2011.

14. Moon HG, Kim SH, Gao J, Quan T, Qin Z, Osorio JC, Rosas IO, Wu M, Tesfaigzi Y and Jin Y: CCN1 secretion and cleavage regulate the lung epithelial cell functions after cigarette smoke. Am J Physiol Lung Cell Mol Physiol 307: L326-L337, 2014.

15. Shahzeidi S, Mulier BD, de Crombrugghe B, Jeffery PK, McAnulty RJ and Laurent GJ: Enhanced type III collagen gene expression during bleomycin induced lung fibrosis. Thorax 48: 622-628, 1993

16. Chen C, Shi L, Li Y, Wang X and Yang S: Disease-specific dynamic biomarkers selected by integrating inflammatory mediators with clinical informatics in ARDS patients with severe pneumonia. Cell Biol Toxicol 32: 169-184, 2016

17. Cui X, Zeni F, Vodovitz Y, Correa-de-Araujo R, Quezado M Roberts A, Wahl S, Danner RL, Banks SM, Gerstenberger E, et al: TGF-beta1 increases microbial clearance but worsens lung injury during Escherichia coli pneumonia in rats. Cytokine 24: 115-127, 2003.

18. Dhainaut JF, Charpentier J and Chiche JD: Transforming growth factor-beta: A mediator of cell regulation in acute respiratory distress syndrome. Crit Care Med 31 (Suppl 4): S258-S264, 2003.

19. Fahy RJ, Lichtenberger F, McKeegan CB, Nuovo GJ, Marsh CB and Wewers MD: The acute respiratory distress syndrome: A role for transforming growth factor-beta 1. Am J Respir Cell Mol Biol 28: 499-503, 2003.

20. Lin J, Tian J, Wang L, Wu W, Li H, Wang X, Zeng X and Zhang W: Apoptosis and surfactant protein-C expression inhibition induced by lipopolysaccharide in AEC II cell may associate with NF- $\kappa \mathrm{B}$ pathway. J Toxicol Sci 42: 53-61, 2017.

21. Yang KY, Arcaroli JJ and Abraham E: Early alterations in neutrophil activation are associated with outcome in acute lung injury. Am J Respir Crit Care Med 167: 1567-1574, 2003.

22. Boots AW, Gerloff K, Bartholomé R, van Berlo D, Ledermann K Haenen GR, Bast A, van Schooten FJ, Albrecht C and Schins RP: Neutrophils augment LPS-mediated pro-inflammatory signaling in human lung epithelial cells. Biochim Biophys Acta 1823: 1151-1162, 2012

23. Cabrera-Benítez NE, Pérez-Roth E, Ramos-Nuez Á, Sologuren I, Padrón JM, Slutsky AS and Villar J: Inhibition of endotoxin-induced airway epithelial cell injury by a novel family of pyrrol derivates. Lab Invest 96: 632-640, 2016.

24. Chuang CY, Chen TL, Cherng YG, Tai YT, Chen TG and Chen RM: Lipopolysaccharide induces apoptotic insults to human alveolar epithelial A549 cells through reactive oxygen species-mediated activation of an intrinsic mitochondrion-dependent pathway. Arch Toxicol 85: 209-218, 2011.
25. MacRedmond R, Singhera GK and Dorscheid DR: Erythropoietin inhibits respiratory epithelial cell apoptosis in a model of acute lung injury. Eur Respir J 33: 1403-1414, 2009.

26. Muroya M, Chang K, Uchida K, Bougaki M and Yamada Y: Analysis of cytotoxicity induced by proinflammatory cytokines in the human alveolar epithelial cell line A549. Biosci Trends 6: 70-80, 2012.

27. Rodríguez-González R, Ramos-Nuez Á, Martín-Barrasa JL, López-Aguilar J, Baluja A, Álvarez J, Rocco PR, Pelosi P and Villar J: Endotoxin-induced lung alveolar cell injury causes brain cell damage. Exp Biol Med (Maywood) 240: 135-142, 2015.

28. Shao L, Meng D, Yang F, Song H and Tang D: Irisin-mediated protective effect on LPS-induced acute lung injury via suppressing inflammation and apoptosis of alveolar epithelial cells. Biochem Biophys Res Commun 487: 194-200, 2017.

29. Fong YC, Maa MC, Tsai FJ, Chen WC, Lin JG, Jeng LB, Yang RS, Fu WM and Tang CH: Osteoblast-derived TGF-beta1 stimulates IL-8 release through AP-1 and NF-kappaB in human cancer cells. J Bone Miner Res 23: 961-970, 2008

30. Livak KJ and Schmittgen TD: Analysis of relative gene expression data using real-time quantitative PCR and the 2(-Delta Delta C(T)) method. Methods 25: 402-408, 2001

31. Akbarshahi H, Sam A, Chen C, Rosendahl AH and Andersson R: Early activation of pulmonary TGF- $\beta 1 / \mathrm{Smad} 2$ signaling in mice with acute pancreatitis-associated acute lung injury. Mediators Inflamm 2014: 148029, 2014.

32. Scorrano L and Korsmeyer SJ: Mechanisms of cytochrome c release by proapoptotic BCL-2 family members. Biochem Biophys Res Commun 304: 437-444, 2003.

33. Lin WC, Chen CW, Huang YW, Chao L, Chao J, Lin YS and Lin CF: Kallistatin protects against sepsis-related acute lung injury via inhibiting inflammation and apoptosis. Sci Rep 5: 12463 , 2015.

34. Dolinay T, Kim YS, Howrylak J, Hunninghake GM, An $\mathrm{CH}$, Fredenburgh L, Massaro AF, Rogers A, Gazourian L, Nakahira K, et al: Inflammasome-regulated cytokines are critical mediators of acute lung injury. Am J Respir Crit Care Med 185: 1225-1234, 2012.

35. Chen CC and Lau LF: Deadly liaisons: Fatal attraction between $\mathrm{CCN}$ matricellular proteins and the tumor necrosis factor family of cytokines. J Cell Commun Signal 4: 63-69, 2010.

36. Feng T, Yunfeng N, Jinbo Z, Zhipei Z, Huizhong Z, Li L, Tao J and Yunjie W: Single immunoglobulin IL-1 receptor-related protein attenuates the lipopolysaccharide-induced inflammatory response in A549 cells. Chem Biol Interact 183: 442-449, 2010.

37. Aloisi F, Carè A, Borsellino G, Gallo P, Rosa S, Bassani A, Cabibbo A, Testa U, Levi G and Peschle C: Production of hemolymphopoietic cytokine s (IL-6, IL-8, colony-stimulating factors) by normal human astrocytes in response to IL-1 beta and tumor necrosis factor-alpha. J Immunol 149: 2358-2366, 1992.

38. Shi L, Dong N, Ji D, Huang X, Ying Z, Wang X and Chen C: Lipopolysaccharide-induced CCN1 production enhances interleukin-6 secretion in bronchial epithelial cells. Cell Biol Toxicol 34: 39-49, 2018

39. Butt Y, Kurdowska A and Allen TC: Acute lung injury: A clinical and molecular review. Arch Pathol Lab Med 140: 345-350, 2016.

40. Hurst V VI, Goldberg PL, Minnear FL, Heimark RL and Vincent PA: Rearrangement of adherens junctions by transforming growth factor-beta1: Role of contraction. Am J Physiol 276: L582-L595, 1999.

41. Sureshbabu A, Syed MA, Boddupalli CS, Dhodapkar MV, Homer RJ, Minoo P and Bhandari V: Conditional overexpression of TGF 1 promotes pulmonary inflammation, apoptosis and mortality via TGFßR2 in the developing mouse lung. Respir Res 16: 4, 2015.

42. Pittet JF, Griffiths MJ, Geiser T, Kaminski N, Dalton SL, Huang X Brown LA, Gotwals PJ, Koteliansky VE, Matthay MA and Sheppard D: TGF-beta is a critical mediator of acute lung injury. J Clin Invest 107: 1537-1544, 2001.

43. Naruse T, Aoki M, Fujimoto N, Arase S, Oura H, Ueda Y and Ikeda A: Novel ALK5 inhibitor TP0427736 reduces TGF- $\beta$ induced growth inhibition in human outer root sheath cells and elongates anagen phase in mouse hair follicles. Pharmacol Rep 69: 485-491, 2017.

44. Bardales RH, Xie SS, Schaefer RF and Hsu SM: Apoptosis is a major pathway responsible for the resolution of type II pneumocytes in acute lung injury. Am J Pathol 149: 845-852, 1996.

45. Aggarwal S, Dimitropoulou C, Lu Q, Black SM and Sharma S: Glutathione supplementation attenuates lipopolysaccharide-induced mitochondrial dysfunction and apoptosis in a mouse model of acute lung injury. Front Physiol 3: 161, 2012.

46. Borner C: The Bcl-2 protein family: Sensors and checkpoints for life-or-death decisions. Mol Immunol 39: 615-647, 2003. 
47. Doghman M, Arhatte M, Thibout H, Rodrigues G, De Moura J, Grosso S, West AN, Laurent M, Mas JC, Bongain A, et al: Nephroblastoma overexpressed/cysteine-rich protein 61/connective tissue growth factor/nephroblastoma overexpressed gene-3 (NOV/CCN3), a selective adrenocortical cell proapoptotic factor, is down-regulated in childhood adrenocortical tumors. J Clin Endocrinol Metab 92: 3253-3260, 2007.

48. Pahl HL: Activators and target genes of Rel/NF-kappaB transcription factors. Oncogene 18: 6853-6866, 1999.

49. Nighot M, Rawat M, Al-Sadi R, Castillo EF, Nighot P and Ma TY: Lipopolysaccharide-induced increase in intestinal permeability is mediated by TAK-1 activation of IKK and MLCK/MYLK gene. Am J Pathol 189: 797-812, 2019.

50. Lopez AD, Avasarala S, Grewal S, Murali AK and London L: Differential role of the Fas/Fas ligand apoptotic pathway in inflammation and lung fibrosis associated with reovirus $1 / \mathrm{L}$-induced bronchiolitis obliterans organizing pneumonia and acute respiratory distress syndrome. J Immunol 183: 8244-8257, 2009.

51. Matsui K, Fine A, Zhu B, Marshak-Rothstein A and Ju ST: Identification of two NF-kappa B sites in mouse CD95 ligand (Fas ligand) promoter: Functional analysis in T cell hybridoma. J Immunol 161: 3469-3473, 1998.

52. White MK, Baireddy V and Strayer DS: Natural protection from apoptosis by surfactant protein A in type II pneumocytes. Exp Cell Res 263: 183-192, 2001.
53. Cheng DS, Han W, Chen SM, Sherrill TP, Chont M, Park GY, Sheller JR, Polosukhin VV, Christman JW, Yull FE, et al: Airway epithelium controls lung inflammation and injury through the NF-kappa B pathway. J Immunol 178: 6504-6513, 2007.

54. Gu LZ, Sun H and Chen JH: Histone deacetylases 3 deletion restrains PM2.5-induced mice lung injury by regulating $\mathrm{NF}-\kappa \mathrm{B}$ and $\mathrm{TGF}-\beta / \mathrm{Smad} 2 / 3$ signaling pathways. Biomed Pharmacother 85: 756-762, 2017.

55. Rosendahl A, Checchin D, Fehniger TE, ten Dijke P, Heldin CH and Sideras P: Activation of the TGF-beta/activin-Smad2 pathway during allergic airway inflammation. Am J Respir Cell Mol Biol 25: 60-68, 2001.

56. Sharp C, Millar AB and Medford AR: Advances in understanding of the pathogenesis of acute respiratory distress syndrome. Respiration 89: 420-434, 2015.

This work is licensed under a Creative Commons Attribution-NonCommercial-NoDerivatives 4.0 International (CC BY-NC-ND 4.0) License. 